\title{
COMPARITIVE STUDY BETWEEN THE DEFLECTION OF PRISM IN POLYPROPYLENE FIBRE REINFORCED HIGH STRENGTH CONCRETE BOTH IN THEORETICAL AND ANALYTICAL
}

\author{
Sathish Kumar. $\mathbf{M}^{1}$, Nithiya Sree. $T^{2}$ \\ ${ }^{1}$ Assistant Professor, Civil Engineering, Velammal College of Engineering and Technology, Madurai, Tamil Nadu, \\ India.mdsathishkumar@gmail.com \\ ${ }^{2}$ Former Student, Civil Engineering, Thiagarajar College of Engineering, Madurai, Tamil Nadu, India. \\ nithiyasree1989@gmail.com
}

\begin{abstract}
In this paper a detail discussion about deflection of concrete prism in polypropylene fibre reinforced High Strength Concrete was done in both theoretical and analytical method. Polypropylene Fibre (Non Metallic Fibre) was used in this work with different proportions in concrete with the range of $0.1 \%, 0.2 \%, 0.3 \%, 0.4 \%$ \& $0.5 \%$. Concrete compressive strength of $80 \mathrm{~N} / \mathrm{mm}^{2}$ was achieved by trial and error method and marked as a reference Control Specimen. 6 concrete mixes including control specimen prism were casted and tested for 2-point loading condition. Analytical study was done by using STAAD.pro and it was compared with the theoretical results. Both of the result indicates the similar values and it was discussed below in detail.
\end{abstract}

Keywords: High strength concrete, polypropylene fibre, STAAD.pro.

***.

\section{INTRODUCTION}

High Strength Concrete (HSC), which was the inevitable name at present in construction field. In the earlier period any concrete mixtures having $40 \mathrm{~N} / \mathrm{mm}^{2}$ or more compressive strength at 28 days were designed as High Strength Concrete. Later this trend was changed and if the compressive strength lies in the range of $60-100 \mathrm{~N} / \mathrm{mm}^{2}$ was commercially accepted as a High Strength Concrete [6]. The key advantage of High Strength Concrete was it is very much strong in compression and poor in tension. Fibres any type which having the ability to arrest the crack by bridging the adjacent concrete while loading. Introducing fibres in concrete was not a new concept, it was historically performed in early 1900s using horse hair, straw in mortar and mud. By the 1960s, artificial fibres were used by researchers in concrete [5]. In this study polypropylene fibre in the range of $0.1 \%, 0.2 \%, 0.3 \%, 0.4 \%$ \& $0.5 \%$ were composited in concrete prism. The prism was subjected to 2point loading and flexural strength of concrete prism was calculated from the test results.

In this work the deflection of prism was calculated manually by using Macaulay's method and this result was compared with STAAD.pro results. Due to advancement of technology, we created software to make things easier and time saving. As a result in the civil engineering point of view the manual design and experimental work had lost its importance in some areas. The main objective of this study is to determine the deflection of concrete prism manually and it was compared with analytical deflection results.

\section{MATERIAL PROPERTIES}

AND

\section{METHODOLOGY}

Ordinary Portland Cement of 53 grade was used in this study. To improve the strength characteristics of concrete microsilica was replaced to cement with different percentage in concrete. Locally available river sand and crushed granite were used as fine aggregate and coarse aggregate. The polycarboxylic based ether (superplasticizer) was used in concrete to produce high workability concrete. Polypropylene fibre was incorporated in concrete to improve the mechanical properties of concrete. Mix proportion for M80 was arrived at by trial and error method according to ACI 211.4r [4], by varying the cement quantity, microsilica quantity. Microsilica quantity was varied from 0 to 10 percent. The mix with 5 percent microsilica gave the higher strength which was considered as control specimen. A total of 6 concrete mixes were used in this investigation. The details of mix proportion are shown in Table 1 , the mix designation and specimen details are shown in Table 2. After 28 days of curing the specimens were subjected to 2point loading test.

Table-1: Mix Proportion

\begin{tabular}{|c|c|c|c|c|c|c|}
\hline Material & Cement & Microsilica & Fine Aggregate & Coarse Aggregate & Water & Superplasticizers \\
\hline Weight $\left(\mathbf{k g} / \mathbf{m}^{\mathbf{3}}\right)$ & 691.15 & 36.38 & 657.64 & 900 & 189 & 10.9 \\
\hline
\end{tabular}


Table-2: Mix Details

\begin{tabular}{|c|c|c|}
\hline $\begin{array}{c}\text { Mix } \\
\text { Designation }\end{array}$ & $\begin{array}{c}\text { \% of } \\
\mathbf{P P F}\end{array}$ & $\begin{array}{c}\text { Compressive } \\
\text { Strength }\left(\mathbf{N} / \mathbf{m m}^{2}\right)\end{array}$ \\
\hline $\mathrm{CS}$ & 0 & 80.21 \\
\hline $\mathrm{P}_{1}$ & 0.1 & 80.23 \\
\hline $\mathrm{P}_{2}$ & 0.2 & 80.47 \\
\hline $\mathrm{P}_{3}$ & 0.3 & 80.50 \\
\hline $\mathrm{P}_{4}$ & 0.4 & 80.77 \\
\hline $\mathrm{P}_{5}$ & 0.5 & 80.30 \\
\hline
\end{tabular}

\section{RESULTS AND DISCUSSIONS}

\subsection{Compressive Strength Test}

Concrete cubes of size $150 \mathrm{~mm}$ x $150 \mathrm{~mm}$ x $150 \mathrm{~mm}$ were cast and tested for compressive strength in compression testing machine of $3000 \mathrm{kN}$ capacity. Studies from the test results show clearly that the addition of fibres gradually varies the compressive strength of concrete upto $0.4 \%$ and there is a light reduction in strength at $0.5 \%$. The variation in compressive strength is due to the perfect bond between the fibre and the matrix. Among the 6 combinations, $\mathrm{P}_{4}$ gave the highest increase in compressive strength of 80.77 $\mathrm{N} / \mathrm{mm}^{2}$. The test results indicate that there is no wide range of compressive strength variations due to the additions of polypropylene fibre. Test results are shown in Table 2.

\subsection{FLEXURAL STRENGTH TEST}

Figure 1 shows the flexural strength test setup in a $1000 \mathrm{kN}$ capacity Universal Testing Machine for prism specimen of size $100 \mathrm{~mm} \times 100 \mathrm{~mm}$ x $500 \mathrm{~mm}$. All the prisms were instrumented and loaded with simply supported condition and it was tested under 2-point loading up to failure. The experimental results point out that the addition of fibre increases the load carrying capacity of High Strength Concrete under flexure and it was given in Table 3 .

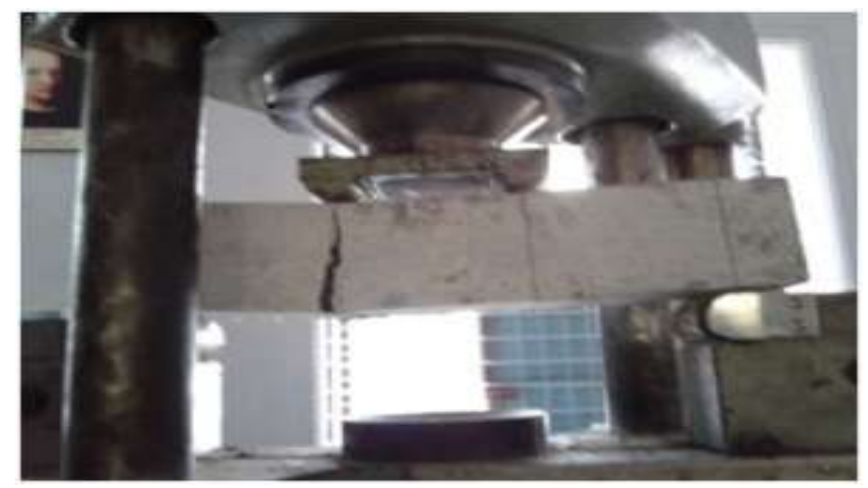

Figure-1: Flexural Tensile Strength Test Setup
Table-3: Flexural Strength Result

\begin{tabular}{|c|c|c|}
\hline $\begin{array}{c}\text { Mix } \\
\text { Designation }\end{array}$ & $\begin{array}{c}\text { Flexural Load } \\
(\mathbf{k N})\end{array}$ & $\begin{array}{c}\text { Flexural } \\
\text { Strength } \\
\left(\mathbf{N} / \mathbf{m m}^{\mathbf{2}}\right)\end{array}$ \\
\hline $\mathrm{CS}$ & 12 & 4.80 \\
\hline $\mathrm{P}_{1}$ & 12.23 & 4.89 \\
\hline $\mathrm{P}_{2}$ & 15 & 6.00 \\
\hline $\mathrm{P}_{3}$ & 15.37 & 6.15 \\
\hline $\mathrm{P}_{4}$ & 16 & 6.40 \\
\hline $\mathrm{P}_{5}$ & 12.28 & 4.91 \\
\hline
\end{tabular}

In this paper an attempt was made to find the deflection of concrete prism indirectly by using STAAD.Pro software and it was checked with manually calculated deflection values. Theoretical deflection values were calculated by using Macaulay's Method. This method was well known by everyone for its convenient to determine the deflection of beams. A prism of size $100 \mathrm{~mm}$ x $100 \mathrm{~mm}$ x $500 \mathrm{~mm}$ was modeled using STAAD.Pro and it was shown in Figure 2. The prism was placed in simply supported condition at a distance of $50 \mathrm{~mm}$ from either side and properties of concrete like Compressive Strength, Young's modulus, Poisson's ratio as mentioned in Table 4 were used in STAAD.Pro for determining the deflection value. From the test results it has been clearly observed that the load carrying capacity of concrete was getting increased by the addition of fibres. Comparing the theoretical and analytical deflection values the test results clearly explains the deflection values were very closer to the theoretical value. Figure 3 shows the deflection value. Table 4 shows the test results.

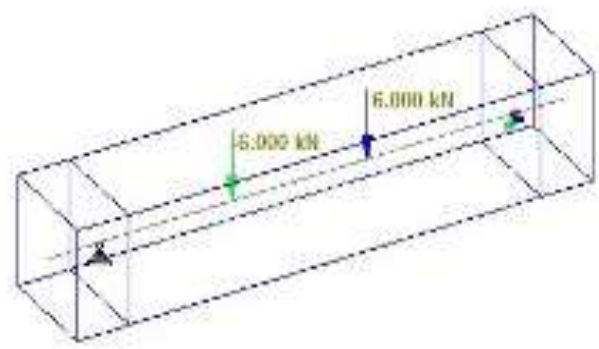

Figure-2: Model of Prism Created using STAAD.Pro

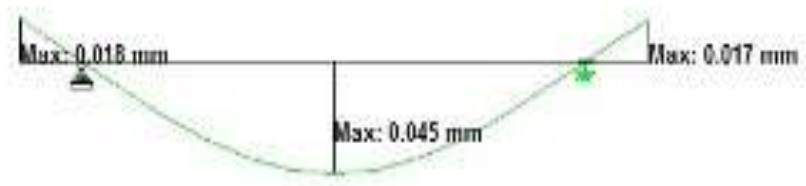

Figure 3. Deflection Value 


\begin{tabular}{|c|c|c|c|c|}
\hline \multicolumn{5}{|c|}{ Table-4: Test Result } \\
\hline 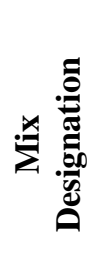 & 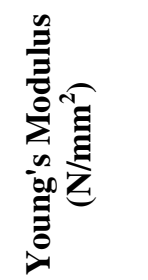 & 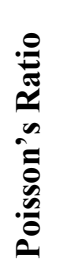 & 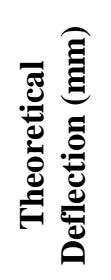 & 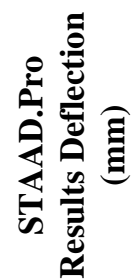 \\
\hline $\mathrm{CS}$ & 36633.93 & 0.17 & 0.032 & 0.045 \\
\hline $\mathrm{P}_{1}$ & 36637.64 & 0.17 & 0.033 & 0.046 \\
\hline $\mathrm{P}_{2}$ & 36682.08 & 0.17 & 0.049 & 0.056 \\
\hline $\mathrm{P}_{3}$ & 36687.64 & 0.17 & 0.051 & 0.057 \\
\hline $\mathrm{P}_{4}$ & 36737.55 & 0.17 & 0.055 & 0.06 \\
\hline $\mathrm{P}_{5}$ & 36650.61 & 0.17 & 0.033 & 0.046 \\
\hline
\end{tabular}

\section{BIOGRAPHIES}

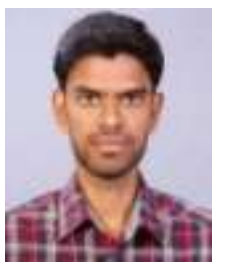

Mr.M.Sathish Kumar, M.E. $\mathrm{He}$ is currently working as Assistant Professor in the Department of Civil Engineering at Velammal College of Engineering and Technology, Madurai, Tamil Nadu. His area of research work is study of High Strength Concrete. Email id: mdsathishkumar@gmail.com

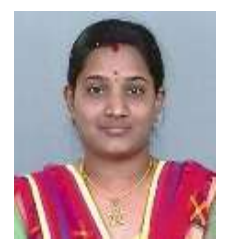

Mrs.T.Nithiya Sree, M.E. She is a former student of Thiagarajar college of Engineering, Madurai, Tamil Nadu. Her area of research work is study of Fibre Reinforced Concrete. Email id: nithiyasree1989@gmail.com

\section{CONCLUSIONS}

The following conclusions are drawn from the results were given below.

1. There is significant increase in loading carrying capacity of High Strength Fibre Reinforced Concrete under flexure, with addition of polypropylene fibre.

2. Comparing theoretical and analytical results, the values obtained through STAAD.Pro was merely close to theoretical result.

3. It is true that using software is easy and time saving and mostly results are comparatively accurate.

\section{REFERENCES}

[1]. Ahsana Fathima K, M \& Shibi Varghese. (2014). "Behavioural Study of Steel Fibre and Polypropylene Fibre Reinforced Concrete." International Journal of Research in Engineering \& Technology. 17-24.

[2]. Hamid Pesaran Behbahani, Behzad Nematollahi, Abdul Rahman Mohd. Sam \& Lai F C. Flexural. (2012). "Behaviour of Steel - Fibre - Added - RC (SFARC) Beams with C30 and C50 classes of Concrete." International Journal of Sustainable Construction Engineering \& Technology.

[3]. Jyoti Narwal, Ajay Goel, Devender Sharma, Kapoor D R \& Bhupinder Singh. An Experimental Investigation on Structural Performance of Steel Fibre Reinforced Concrete Beam. International Journal of Engineering and Advanced Technology. 2013; 2.

[4]. Reported by ACI Committee 211.4r. Guide for Selecting Proportions for High Strength Concrete with Portland Cement and Fly Ash.

[5]. http://en.wikipedia.org/wiki/Fiber-reinforced_concrete

[6]. http://www.ce.berkeley.edu/ paulmont/241/HSC.pdf 